\title{
Śmierć wstydu. O zjawisku skandalu w najnowszej prozie polskiej po roku 1989
}

Adam Mazurkiewicz 


\section{Adam Mazurkiewicz}

\section{Śmierć wstydu' ${ }^{1}$ O zjawisku skandalu w najnowszej prozie polskiej po roku 1989}

\footnotetext{
Cezura roku 1989, urastająca w powszechnej świadomości do rangi symbolu, jest wygodnym (choć stereotypowym) momentem, od którego zwyklo się datować nowy okres w dzicjach rodzimej literatury. Nie należy jednak zapominać, że

...nic w historii kultury nie rodzi się z dnia na dzień. To, co objawia się nagle pod postacią wyrazistego zjawiska, jest zawsze eféktem procesów, które na dłıgo przedtem drążyły podskómie życie, dochodząc do głosu sporadycznie ${ }^{2}$.
}

Również nowa koncepcja literatury ani spoleczne na nią zapotrzebowanie nie pojawiły się po roku 1989 niczym deus ex machina, zadekretowane czytehniczą umową bądź odgómą decyzją. Istotnie: przesilenie wrażliwości literackiej zbiegło się wprawdzie (jak to zazwyczaj bywa) z przemodelowaniem życia społecznego i przelomen politycznym. Jednakze grunt pod „nową literaturę" przygotowany był już na dhugo przed debiutami tych, których okrzyknięto jej "nadwornymi minstrelami”. Próbując wyznaczyć nowe granice literackości, twórcy ci sięgnęli do estetyki modnego na Zachodzie postmodernizmu, odczytywanego najczęściej jako alternatywa dla twórczości wiernej pozaliterackim zobowiązaniom etycznym, wplywającym zwlaszcza na literaturę lat siedemdziesiątych i osiendziesiątych.

Jedną z praktyk, która - szczególnie wśród pisarzy młodych dorobkiem - zyskała popularność, stało się nagmimne wykorzystywanie estetyki skandalu. Stanisław Burkot dostrzega w manierze epatowania czytelnika zamierzoną wulgarnością i kolokwializmem języka literackie urzeczywistnienie kontestacyjnych deklaracji autorów z kręgu ,bruLionu”, między in-

\footnotetext{
1 Okréślenic Krzysztofa Andrzcjczaka: zob. idem, Smienc u'sty'du. „Litcratura” 1999 nr 1.

2. Czapliński. P. Śliwiński. Literatma polsku 1976-1998. Praenodmik po prozic i poezii. Kraków 1999, s. 235.
} 
nymi Manueli Gretkowskiej i Andrzeja Stasiuka ${ }^{3}$. Można w owych skandalizujących dzialaniach twórców „bruLionu” upatrywać dwojaki sens: nie tylko bowiem zaistnieli oni w świadomości czytelniczej, ale i (przynajmniej częściowo) stworzyli własną tożsamość. Demaskowanie utożsamiania zashug politycznych dzialaczy opozycji ze zdolnościami literackimi i veto wobec odczytywania literatury przez pryzmat kryterium etycznego towarzyszyło licznym zlośliwościom i personalnym wycieczkom wobec twórców związanych z „drugim obiegiem”" Napastliwy ton „bruLionowych” polemik, bezkompromisowość ocen, zjadliwość i zamierzona obrazoburczość (jej swoistą kwintesencją zdają się Kazania Himmlera i rasistowskie w wymowie utwory Ezry Pound a w numerze 17/18 pisma) korespondowaly z estetyką art-zinów i i happeningóu' organizowanych przez animatorów kultury alternatywnej. Ostentacyjna kontestacja kultury oficjalnej (ale też i opozycyjnego „drugiego obiegu”, związanego z ruchem solidarnościowym i emigracją) w dzialaniach twórczych Totartu, Pomarańczowej Alternatywy i innych grup stały się źródlem beletrystyki, którą można byloby określić mianem „literatury bez zobowiązań”, jako że „. maporty z rzeczywistości” (a za takie przyjdzie uznać utwory głównie młodych dorobkiem twórczym autorów, jak Tartak Daniela Odiji, Osiem czter' Mirosława Nahacza, Can'arte niebo Mariusza Sieniewicza), to nie tyle świadectwa zaangażowania, co uświadomienie sobie jego niemożności'. Wszak, jak zauważa Dariusz Nowacki, młodzi „frustraci”, któryclı bunt jest

...napędzany złością, nic wierzą w moc krytycznego i glęboko osadzonego w rzeczywistości spolecznej slowa ${ }^{7}$.

ucickając w intertekstualne gry w udawanie. Jako pars pro toto może służyć nam przyklad Czu'artego nieba Sieniewicza, będącego zarówno powiéścią o imitacji kapitalistycznego raju, jak i imitującą poetykę Gombrowicza, Buthakuwa, Dostojewskiego oraz powieści zaangażowanej. Mówienie o związkach Camartego nieba z rzeczywistością pozatekstową zostają uprawomocnione expressis u'erbis uwag̨ narratora, wedle którego w powieści czytelnikowi zostaje zaprezentowany

'Zob. S. Burkot, Literatura polska "1 latach 1986-1995. Kraków 1996, s. 83.

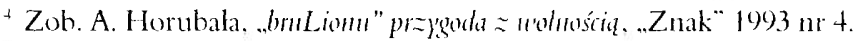

" „ART ZINE ( $z$ ang. ant(mugra) zime), takż ART ZIN lub ARTZIN — prywatne alternatywne pisma literackie preparowane manufakturowo przez swoich autorów najczęściej odbijane na ksero (ale często też drukowane) rozchodzące siç glównic w niczalcżnej sicci dystrybucji pocztowej" (Parmas bis. Ston'mik litcratury polskicj urodzo ncj po 1960 roku. oprac. K. Varga, 1. Dunin-Wąsowicz, Warszawa 1995, s. 9, hasło Artzinc').

" Wprawdzic. zdauiem Nahacza, ., ćpaniu i imprezowaniu pisalo bardzo duzo ludzi, (...) myślę. że w wspólczesncj książce. która porusza taka tematykę̧. nie chodzi ó ćpanie. W tych książach są poruszane wiçksz tematy, a to, że siç je porusza za pomocą tego. to jest to po prostu narzędzie. Jest tak, że w tych ksiązkach możn

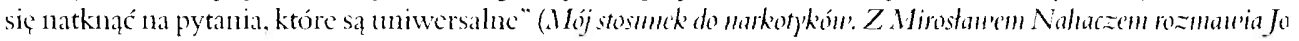
anma Danceka, ..EMPIK News", czerwiec 20(1)4. s. +2), jeduak stowa te pozostają deklaracją, której oddźwiçk nie można znaleźć na kartach ()siem catern'.

D. Nowacki. Ztosí nicprzedstuniona. ... Gazeta Wyborcza” 20 paździcrnika 2003.

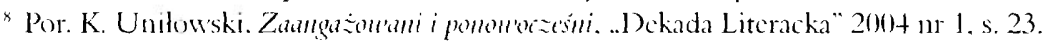


...wytarty świat jak z kolejnej książki o pokoleniu, kolejnej literackicj wersji bezsensu wypchanej watą pseudointeligencji, grzęznącej w infantylności, gdzie pozerstwo i bycie kul [sic! jest pierwszym przykazaniem. Znowu Kohelet. Powtarzalność, zgaga, blaga".

De facto literatura bez zobowiązań stanowi nierzadko kuriozalny mariaż pseudoartystycznego chaosu językowego i publicystycznic traktowanej tematyki - znamiennym przykładem służyć może powieść Chłopi III Zbigniewa Sajnoga i Tymona Tymieckiego bądź utwór Pawła Przywary Annezja (1995). Bohaterem ostatnicj z przywolanych tu powieści jest zawodowy morderca - Samiec Gula - sprowadzony do Polski, by zwalczać kommizm, uosobiony w postaci Szatana".

Twórczość, określana tu mianem „literatury bez zobowiązan”, miala programowo odrzucać ethos pisarza-sumienia spolecznego". Alternatywą dla postawy etycznej - znamiennej dla twórców podejmujących problematykę społeczną na przełomie lat siedendziesiątych i osiemdziesiątych ubieglego stulecia - stako się permanentne eksperymentatorstwo ${ }^{12}$. Immymi stowy, dylematy moralne, obecne w prozic okresu stanu wojennego, zastapione zostaly po roku 1989 coraz wyraźniejszymi tendencjanni do tworzenia fikcyjnych opowieści z potencjalnie atrakcyjnych dla czytelnika wydarzeń: tendencję tę zauważal Jerzy Jarzębski, którego zdaniem

...wygasa lub traci na naszych oczach istotność (...) pewien typ prozy, która za rzecz najważniejszą miala prezentację autora jako enigmy, towarzyszenie jego

${ }^{9}$ M. Sicnicwicz. Czmatte niclo. Warszawa 20(13, s. 166.

"O powicści Przywary. nic adnotowancj, hotabene, przez wiçkszość autorów prac zajumljących się literaturą najnowszą, wspomina Pawel Dunin-Wassowicz. Autor Oka smoka traktuje ja jako pretekst do siçgniçcia po poetykę wykorzystywaną przez autorów kojarzonych z .,rewolucja artystyczną w prozic" (Jan 1)zezdżon, Ryszard Szubert. Marek Słyk) - zob.: P. Dunin-Wąsowicz. Oko smoka. Literatma tzur. Pokolenia "bruLiomu" u'olec III R. P., Warszawa 200)( s. 67-68.

"Kres instytucji pisarza-sumicnia spolecznego to oczywiścic zjawisko szersze i odnoszące siç nie tylko do twórczości debiutantów lat dzicwiçédziesiątych. Pisarza-wzorzec do naśladowania zastappil pisarz-dostarczycicl fikcji. Do sytuacji tej można odnicść komentarz Przemyslawa Cizaplińskicgo: ..Pisarze nic będą już pelnić roli "spolecznego senatu", wybrancgo w milezącej zgodzie przez spoleczeństwo, a spoleczeństwo nie będzic już czekako na milezenic pisarza i nic będzie go rozliczało ze slów. Kondycic pisarza, literatury i odbiorcy okre-

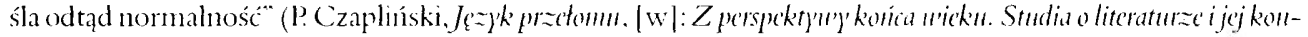
tekstach, red. J. Abrannowska. A. Brodzka, Pozmań 1997, s. 287), pozostająca nickiedy zgodą na intelektualna plytkość. Na temat sytuacji literatury i kultury po przcłomic roku 1989 zob. równicz: S. Piskor, Nou'c un'annm-

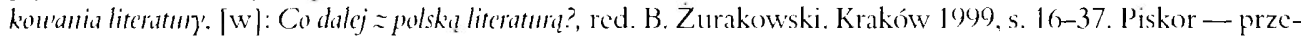
ciwnic niz Czapliński - nic tylko nic dostrzega kresu spolecznych tinkcji pisarza (jako glosu sumienia, straznika panięcei, itd.), lecz w nich wlaśnic upatruje sensu jego istnicnia, jako twórcy literatury, której pozostawia alternatywç: .rola kannerdynera lub busoli spoleczncj nawigacji” (ibidem. s. 36).

12 Oczywiścic nic można zaponinać o twórcach pozostających - z różnych wzglçdów - wicrnynni koncepcji literatury zaangazowancj. Jako przyklad można byłoby tu wymicnić Pouret do Bretenheide Wlodzimicrza Kowalewskiego. Bohater mikropowicści, toczący spór o powinności sztuki, zauważa, iż ta „musi uosabiać najszczytnicjsze idec" (W. Kowalewski. Ponrót do Breitenheide, Warszawa 1908, s, 166): inna z postaci stwicrdza: „sztuka to pocieszenic. Sprawia, że czuję siç więcej warta, niż naprawdẹ jestem“ (hor. cit.). Nic bez znaczenia oczywiścic pozostaje czas akcji utworu Kowalewskicgo - modernizm. Jednak i w twórczości sytuującej fabulę wspólczéśnic można odualeźć podobne akcenty (Janusz Anderman, Kraj śniata; Jacek Durski, Rok; Dorota Terakowska. Por $\approx$ rarka). 
życiowym przypadkom, zapisywanie, tropienie ich sensu czy wykładni. Tak jakby pisarze - zakochani dotychczas w autentyku — pokochali na nowo fikcję, kreację, jednym słowem - literaturę ${ }^{13}$.

Dodajmy, iż nierzadko o owej atrakcyjności podejmowanej tematyki - co odnosi się zwlaszcza do prozy z kręgu literatury populannej - decydowal jej związek z wydarzeniami polityczno-spolecznymi, do których przyczyniły się przemiany zainicjowane w roku 1989. Zwlaszcza twórcy skandalizującego nurtu fantastyki naukowej, niezdolnej do podjęcia w sposób poważny dyskursu teologicznego, dość często odwoływali się do mitologii społecznej i spiskowej teorii dziejów, ukazując rozbieżności głoszonych postaw i prywatnego życia przedstawicicli hierarchii kościelnej ${ }^{1+}$. Owe „rewelacje” na temat kleru nader często potęgowane bywaly do niezamierzenie groteskowych wymiarów. W utworach takich Kościół ukazany zostaje najczęściej jako zbiurokratyzowana instytucja, nastawiona na doczesny zysk finansowy, czerpany z nielegalnych inwestycji (Miroslaw Jabłoński, Elektryczne banan)', czyli ostatni kontrakt Judasza).

Tendencję przeciwstawną w stosunku do prezentowanej powyżej można zauważyć w twórczości pisarzy, którzy przywoływali postulat Juliana Kornhausera i Adama Zagajewskiego ze Śl'iata nie przedstau'ionego, by realistyczną powieść uczynić „,podstawowym źródłem wiadomości o świecie i ludziach" ${ }^{15}$. Słowa te twórcy literatury lat dziewięćdziesiątych odczytali jako niezgodę na literaturę tworzoną poza (nicjako obok) rzeczywistości. Zarazem powrót do teraźniejszości czytelnika i jej odwzorowanie w świecie przedstawionym utworu ujmował w twórczości „nowych gniewnych” najczęściej jej „egzotyczne” (dla przeciętnego odbiorcy) marginesy. Mur $\rangle^{\prime}$ Hebrom Andrzeja Stasiuka, nowelistyka Marka Nowakowskiego bądź Pod mocny'm aniotem Jerzego Pilcha to pozycje ukazujące „zaklęte rewiry” wspólczesności: świat marginesu społecznego, alkoholików, pensjonariuszy zakładów karnych i poprawczych dla nieletnich. Poszerzaniu tematyki o sygnalizowane tu marginalia rzeczywistości spolecznej towarzyszylo poszukiwanie nowego języka literackiego, tak by „odpowiednie dać rzeczy stowo".

Pozornie odpowiedzią na owo zapotrzebowanie stal się slang ulicy, niewolny od dosadnej metaforyki i wulgarności, będącej językowym obrazem brutalizacji życia spolecznego. Nie należy jednakże zapominać również o innym źródle owego nowego języka rodzimej prozy którym nierzadko bywał spóźniony refleks lektury powieści Henry'ego Millera i reprezentantów amerykańskiego nurtu prozy postmodernistycznej (Johna Bartha, Williama Bur. roughsa, Philipa Rotha).

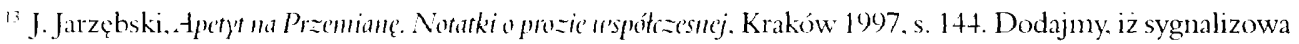
na przez Jarzębskiego fikcjonalność zostaje nickiedy zaprezentowana czytclnikowi w sposób zannicrzenie os tentacyjny: Fikcja, jako świadoma samcj siebic, przechodzi wówczas w sferę metafikcji.

"i Zródlem informacji (czy tcż raczej zbiorem popularnych mitów społecznych) na temat „mroczncj stron

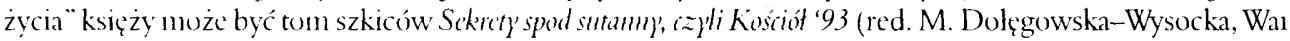
szawa 1993).

15. J. Kornhauscr. A. Zagajowski, Suriat nie przcidstanyony, Kraków 1974, s. 10.
} 
Relatywizm etyczny, niemożność oddzielenia dobra od zła; rzeczy moralnie nagannych od akceptowanych, oddają stan ducha kultury, proponującej postawy etycznie niedopuszczalne i niebezpieczne spolecznie. Aksjologiczny chaos (towarzyszący zwykle przewartościowaniom w sferze życia społecznego) zdawal się fascynować wielu twórców, poszukujących wlasnej drogi artystycznej, nieobciązonej rodzimą tradycją. Obrazowi świata, wylaniającemu się z literackich wizji „pokolenia przełomu”, blisko jest do surrealistyczno-onirycznego koszmaru, niczym z Nagiego lunchu Burroughsa, którego bohater nie może wyrwać się z kręgu halucynogennych wizji, zatracając granicę między rzeczywistością i narkotycznym koszmarem.

Owemu nililizmowi ontologicznemu, przejętemu od amerykańskich postmodemistów, w rodzimej twórczości towarzyszy nierzadko, nie zawsze motywowana w glębszy sposób, zmiana stosunku opowiadającego do przedmiotu opowieści. Twórcy, w dążeniu do oddania bogactwa rzeczywistości pozatekstowej, coraz częścicj „fragmentowali” prezentowany czytelnikowi świat przedstawiony. Rodzący się chaos zdarzeń i ich fragmentaryczność miały być odzwierciedleniem chaosu świata, w którym funkcjonowali autorzy owej prozy ${ }^{\text {th }}$. Czy owemu pragnieniu osiągnięcia „absolutnej mimesis” należy przypisać tendencje do szokowania odbiorcy $^{17}$ ? Wedtug Krzysztofa Andrzejczakia

...dzisiejsza powieść chce, bardziej niż kiedykolwiek w przeszłości (...) burzyć i obrażać. Pisarze prześcigają się w uwalnianiu nas od zasad moralnych i nawyków estetycznych, parodinją to, co nie zostało jeszcze wyśmiane i obalone ${ }^{18}$.

„Efektem ubocznym” okazuje siç próżnia aksjologiczna", wypełniona często wisielczym humnorem: bohaterowie literaccy, bezradni wobec wolności, potrafią przeciwstawić jej tylko iście Gogolowski śmiech. Śmieją się z samych siebie i whasnej sytuacji, lecz źródeł owej wesołości nie należy upatrywać w poczuciu panowania nad światem, lecz bezradności. Śniech ten — niczym surrealistyczny ,humoryzm" Gomeza de la Serny -

In Tendencję do ..rozbijania” wizji świata jednostki Zygmunt Bauman rozpatruje jako sigunum temporis. „Epizodycznośc” $i$ „nickonsekwencja” to - w myśl ustaleń badacza - wlaściwości ponowoczesnego zycia: . rany. z jakinu każde poczynanic życiowe musi się liczyć i na jakic może liczyć, nic znikly - nic sąjednak trwake, jak

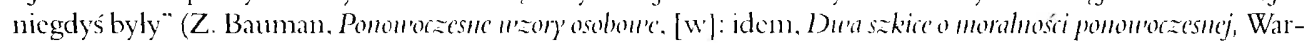
szawa 1994, s. 1t).

${ }^{17}$ Możliwe też. że pisarze ci zasugerowali siç słowami Vladimira Nabokova, który na kartaclı Lolity' (utworu uchodzącego wszak - w myśl stereotypów - za kwintesencję powicści skandalizająccj) zauważat, iz ..wiclkic dziclo sztuki zawsze jest oryginalne, a zatem z samej swej natury winno sprawiać odbiorcy muicj lub bardzicj szokującą niespodziankę" (V. Nabokov, Lolitu. tl. M. Klobukow'ski. Kraków 2004, s. 7). W takim przypadku źródet skandalu należaloby upatrywać w . glodzic arcydzicha". Iednocześnic lata dzicwięćdziesiąte minioncego stulecia nalcży traktować jako świadectwo nicnożności spchnicnia ow ej prośby czytclników o arcydzicło. Najczęścicj niemożność ta jest jawnic dekretowaną odmową. Zwraca na to uwagę Jerzy Jarnicwicz. wedlug którego „literatura ostatnich lat skazala na wieczne wygnanic wiele sków. którymi kiedyś ją opisywano. Wśród nich

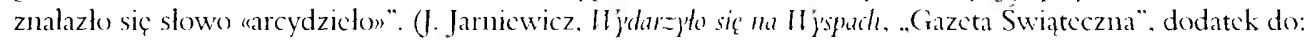
"Gazcta Wyborcza”, 21-22 września 20102, s. 21).

${ }^{1 *}$ K. Andrzcjczak. Śmieré $u$ 'st) $d u$, op. cit., s. 47.

19 Na temat relacji wartości do poczucia normy i związanego z nią wstydu zob. rozmowç Katarzyny Janowskicj i Piotra Mucharskiego z Krzysztofem Piesicwiczem (Ruzmon')' ma konice nicku 1, Kraków 2000), s. 57-67). 
...rozbija rzeczywistość w której odnajduje nieprawdopodobne i kojarzy rozdzielone czasy i rzeczy; wszystko, co istnieje, czyni obcym²0.

W świecie, w którym wszystko istnieje osobno, każde zestawienie jest arbitralne, niekonieczne. Tym samym świat przedstawiony w konfrontacji z czytelniczym przyzwyczajeniem (płynącym z rozpoznawania schematów fabularnych, gatunków bądź motywów) obnaża swą absurdalność, która dezorientuje $e^{21}$. Jako przykład można byłoby przywołać w tym miejscu tom prozy Marcina Bielaka Tyle suriatóu, ile zechcesz. Niejednorodności stylistyczno-tematycznej towarzyszy w nim cyniczny micjscami dystans do opisywanych zdarzeń: znamienny przykład stanowi scena z fragmentu Bandziaroska iśmierć: miasteczko, w którym mieszka tytulowa bohaterka,

...jest male i wielu żebrzących nie utrzyma. Wkrótce Rumuni wynieśli się, a Bandziaroska wieszała na sobie coraz to nowe informacje. Raz była stokrotnie gwatconą Jugosłowianką, cudem ocalałą z pogromu, to znowu chorą na AIISS lub genetycznie obciążona jakimś straszliwym, egzotycznym i śmiertelnym parchem. Kiedy potrącil ją pociąg, niektórym nawet ulżylo, że już nie będzie się kobiecina tak męczyć2

Tragedia bohaterki zostaje skomentowana z ironicznym dystansem, wręcz cynizmem. Temat śmierci żebraczki to dla Bielaka materiał na anegdotę okraszoną makabrycznym, czarnym humorem. Nie jest to jednakże przewrotny humor intelektualny, który można odnaleźć choćby w komiksowej Rodzinie Adamsów' rysownika i pomysłodawcy serii opowieści o niesamowitej rodzinie, Charlesa Adamsa. To żart „populistyczny”, skierowany do szerokich mas spoleczeństwa - zapewne tych samych, które z uwagą śledzą telewizyjne seriale pokroju Śliata u'edtug Kiepskich.

Nastawienie na epatowanie czytelnika koszarowo-grabarskim dowcipem przyczynia się do spłycenia problematyki: Konmusutra Aleksandra Olina bądź Śu içto śmiechu Marka Oramusa to jedynie na pozór rozrachunck z polską rzeczywistością polityczno-spoleczną ostatniego ćwierćwiecza. W istocie jednak obie powieści są autorskimi „wybrykani”, przekraczającymi nierzadko granice dobrego smaku. Jak bowiem inaczej niż w kategoriach próby ekscesu odczytywać scenę ze Śl'ięta śmiechuı, w której zabici robotnicy urządzają pikietę u Bram Nieba?²3

Znacząca dla nowego wizerunku twórcy zdaje siç postawa Reda Vonneguta [Romana Praszyńskiego], autora między innymi Miasta senny yed kobict: zdaniem Dariusza Nowackiego

21) Cyt. za: A. Hutnikicwicz, Od caystej formy do literatur? faktw, Warszawa 1995, s. 145-146.

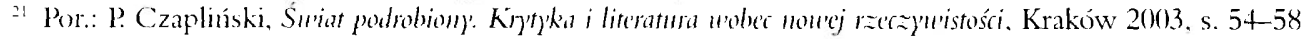
Przemyshaw Czapliński owo wype hnienic śniechem próżni aksjologiczncj (powstałej po odrzuceniu przez li teraturę etycznych zobowiązań) analizuje na przykładzic jedıcgo z opowiadaí Nataszy (iocrke z tomu Fractal - Hizyty. Uwagi badacza i stormulowane przezeń wnioski można jednak odniéśc generalnie do sytuacji bo haterów w nurcie prozy ., rewidującej” dotychczasowe czytelnicze przyzwyczajenia.

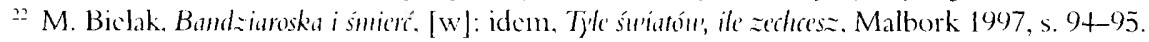

23. Politycznemu rozliczeniu z przeszlością nic towarzyszy w powieści Oramusa refleksja nad dniem dzisiej szym. Obraz wspólezesności, kwitowancj zale dwic kilkoma frazesami, to banalne uwagi o ludzkicj i Bożej nic doskonalości, której skutkiem jest wolnośé dalcka od weześnicjszych wyobrazéń o nicj. 
...drażnienie czytelnika, nieustanne wywoływanic irytacji i dezorientacji - to bodaj nadrzędna ambicja wrocławskiego pisarza ${ }^{2+}$.

Twórczość tę wysoko ocenia Paweł Dunin-Wąsowicz, zestawiający jedną z powieści Na kleczkad - z Buszujacym $u^{\prime}$ zbozu Salingera, by stwierdzić, ze Praszyński ,nie ma żadnego odpowiednika w rówieśniczej sobie rodzimej prozie" ${ }^{25}$. Czy nie jest to jednak ocena na miarę „Trzeciego Parnasu”" ?t? Tym bardziej, że dla literackiego pokolenia „mtodych gniewnych” ostatniej dekady ubiegłego wieku

...literatura jest tylko zabawa, sposobem na życie, ekspresją osobowości twórcy, utrwalaniem czystej egzystencji, jej zawikłań i absurdów ${ }^{27}$.

Nie można jednak nie zauważyć, iż sygnalizowana tu przez Burkota wielość postaw de facto często sprowadzała się do (mniej lub bardziej zamierzonego) obnażania literackości prezentowanych czytelnikowi utworów. Ów .metatekstowy sposób bycia"̌x zaowocowal powrotem fabuły, której towarzyszyla pisarska samoświadomość fikcyjności tego, co zostaje zaprezentowane odbiorcy. Renesans fascynacji możliwościami oferowanymi przez literacką fikcję nie byl jednak równoznaczny z powrotem do zdezaktualizowanej estetyki. Pustkę, powstałą po odrzuceniu pozaliterackich zobowiązań, młodzi twórcy rychło wypehnili modą na antyklerykalizm i kosmopolityzm. W połączeniu z kolokwialnością języka i wulgaryzacją poruszanej tematyki, proces odrzucania etycznych zobowiązań literatury częstokroć doprowadzał do ekshibicjonistycznego obnażania własnych kompleksów. Pozorna nonszalancja, by nie rzec wręcz - lekceważnic przez piewszoosobowego narratora (najczęściej kreowanego na alter ego pisarza) tego, co prezentuje czytelnikowi, ma sprawić wrażenie ,bycia na luzie”. Czy postawa ta jednakże w istocie jest świadectwem owego „luzu”? Narrator powieści Romana Praszyńskiego Na klęckadl deklaruje:

...mieszkam w Zakrzowie. Zakrzów to zadupie Wroclawia. Wroclaw to miasto w Polsce. Polska to zadupie Europy ${ }^{2 !}$.

Ile w tym określeniu własnego miejsca na Ziemi autentycznej swobody, a ile pozy, autokreacji na „nowoczesnego kosmopolitę”? Zachlyśnięcie się wolnością słowa i tym, że ,juz wszystko można", doprowadzilo do powstania wielu utworów mało ambitnych artystycznie.

2+ D. Nowacki, Red doda "am skrzydd. „FA-art” 1997 11r 1, s. 59.

${ }^{25}$ P. Dumin-Wąsowicz. Oko smoka.... op. cit., s. 89.

26 Określenic to przejçte zostało - wraz z ironicznym wydźwiękien - od Przennyslawa Czaplińskiego. który stwierdza: „Dunin chcial (...) nazwać rzecz groźną: literatuma nic rządzi siç prawami literackimi, a hicrarchic nic tworzą siç dziçki rzeczywistym umicjętnościom (...). kto ma poparcic prasy wysokonakladowej, trafia na Parnas prim, kto zaplecza nie ma, spada do Parnasu bis. Uważając to za skandal i hańbę. Dunin (...) uklada Trzeci Parnas. (...) Ukladając Parmas Tertims, autor wrócil (...) do tcj sancj metody. którą chcial zwalczać, to znaczy do pozaliterackiego thumaczenia literatury" (1) Czapliński. Ruchome margines). Kraków 2(1)2. s. 61-62).

27 S. Burkot. Litcratwra polska w latach 1986-1995. op. cit. s. 83.

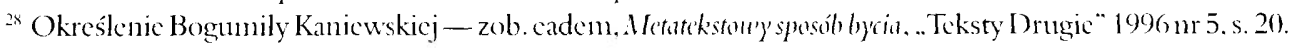

29 Red Vonnegut [R. Praszyński], Na kilgekial,. Wroclaw 1992, s. 11. 
Niekiedy jedyną przyczyną ich pojawienia się byla odpowiedź na zapotrzebowanie spoleczne czytelników, szukających w ,nowej literaturze” sensacji i pikanterii obyczajowej. Wielu z owych "mlodych skandalizujących” rychło zamilkło (jak Krzysztof Bielecki czy Mariusz Bielak), inni znaleźli miejsce w historii literatury najnowszej ${ }^{30}$. Osobną kwestią pozostaje zagadnienie, czy jest to miejsce zasłuzone? Czy istotnie — jak chce Jerzy Jarzębski -

...wszystko można powiedzieć, literatura funkcjonuje w przestrzeni nie nacechowanej wstępnie, nie przegrodzonej ściankami zakazów czy nakazów ${ }^{31}$ ?

Piotr Michałowski proponuje uznanie skandalu za strategię odbioru mającą na celı zaskoczenie czytelnika, a jednocześnie zakłócenie procesu komminacji między nadawcą i odbiorcą. Skandal może wybuchnąć jedynie wtedy, gdy przekroczona zostaje konwencja oczekiwana przez odbiorcę. Tym jest on zaś większy, im mniej spodziewany. Nadawca może wprawdzie projektować odbiór dzieła jako utworu skandalizującego, lecz jest to nadal jedynie prowokacja - podjęta lub też odrzucona przez odbiorcę. Jednakże obecnie, w dobje „rozchwiania aksjologicznego", gdy istnieje powszechne przyzwolenie na zachowania i jawnie gloszone postawy, które dotychczas były raczej nieakceptowane społecznie, eksces stał się strategią oczekiwanią. Tym samym zaś spoleczna tolerancja (akceptacja?) wobec skandalizowania ogranicza jego „silę rażenia”. Nie mależy również zapominać, że skandal - traktowany jako pewna strategia odbioru - wymusza specyficzne zaskoczenie odbiorcy, bowiem

...eksploduje tylko wtedy, gdy naruszenie przewidywań czytelnika jest szczególnie dotkliwe i dotyczy (...) zwlaszcza imponderabiliów ${ }^{32}$.

Innymi slowy: nie każdy „artystyczny wybryk” pisarza można uznać za skandal, nawet jeśli jest on programowo zadekretowany w ten sposób. Czyż bowiem postępowanie takie nie jest swoistym chwytem rynkowym? Le'kia bezpiecznego se'su Marcina Szymuli nie jest bowiem - wbrew zapewnieniom Macieja Parowskiego - utworem „reprezentatywnym dla rozgrzanych spolecznych emocji ${ }^{33}$, których w Polsce nie brakuje”" Absurd ukazanej w utworze sytuacji „oswaja” przy tym skandal, „obezwladniając” go nieco zażenowanym, czytelniczym śmiechem na myśl o uczniach poznających w szkole zasady pożycia intymnego ${ }^{35}$.

\footnotetext{
31) Szczególnym przypadkiem jest pisarstwo Manueli Gretkowskiej, która potrafila wykorzystać skandal me-

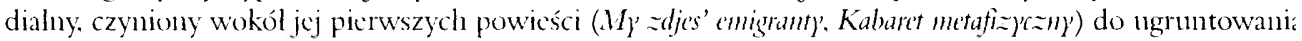
swej pozycji skandalistki. przez której pryzmat udbierana jest jej późnicjsza twórczość.

3 J. Jarzębski. Apettyt na Prsémiusuç, op. cit., s. 125.

32 P. Michalowski. Strategic skamdalu i stereot)'py odbioru. [w]: Stereotyp) i literaturze (i tmi obok), red. W. Bolecki G. Gazda, Warszawa 2003, s. 280. Znamienmą cechą literatury skandalizującej jest fakt, iz owe przekraczani oczekiwań odbiorcy to najezçścicj akty jednorazowe - należy jednak pamiçtać o tym, że „skandal jest prece densent. a nic procedercm" (tamize. s. 290).

33 m. p. [M. Parowski]. Iyde park. .Nowa Fantastyka" 1992 nr 11, s. 44.

it Ibidem.

i" I nic tylko pożycia intymneggo, o czym zdają siç świad czyć slowa nauczyciclki. podająccj rozklad materiałun najblizsze spotkania. Wśród którégo znalazla siç lekeja bezpiecznego spożywania alkoholı, zażywania narkoty
} 
Sztuka moze (...) być prowokacją. Ale to wyzwanie, ta prowokacja, winny do czegoś prowadzić - zastrzegal Antoni Pawlak, rozważając szanse ekscesu jako perspektywy interpretacyjnej w odniesieniu do wspólczesnej sztuki - żeby dokonać prawdziwej prowokacji artystycznej, trzeba czegoś chcieć. Od sztuki, od siebie oraz od świata. Innymi słowy trzeba myśleç $c^{36}$.

Nieporadność stylistyczna i nikła wartość artystyczna zadecydowała o niewykorzystaniu szans, jakie potencjalnie niosto wprowadzenie do twórczości literackiej elementów traktowanych dotychczas w jej obrębie jako non grata. W przypadku większości spośród przywolywanych tu utworów, przekraczanie tabu obyczajowego ogranicza się do epatowania „wymyślnymi" (de facto zaś niesmacznymi i nawnymi) opisanni, mającymi pobudzać wyobraźnię czytelnika ${ }^{37}$. Ponadto cel, dla którego najczęściej literatura odwoluje się obecnie do skandalu, jest prawie zawsze merkantylny Odrobina (nie zawsze z umiaren dawkowanej) pikanterii staje się chwytem marketingowym, mającym zwiększyć sprzedawahność książki: wszak kultura oczerniana rodzi popyt ${ }^{3 x}$. Tym samym eksces staje się motywowany nie tyle estetycznie, co ekonomicznie $^{34)}$. Takie wykorzystanie deprecjonuje jednak istotę skandalu, programowo nastawionego na przełamywanie czytelniczych przyzwyczajeń i skonwencjonalizowanych chwytów literackich.

ków i hazardu. Znanienne tez stają sį̣ wypowiedzianc przez nią stowa, podsumowujące lekcję: . Panniçtajcie - dorosie życie pelne jest zadziwiających propozycji. nicbezpieczeristw. pulapek. Macie wielkie szczęście. Kiedy ponyślę, ze wasi rówicśnicy w XX wicku wychodzili tenu wszysthicmu naprzeciw nic uzbrojeni i nic ostrzeżeni - ogarnia muic przerazenic” (M. Szymula, Lekija bezpicisnego seksu, .Nowa Fantastyka” 1992 nr 11, s. 46).

36 A. Pawlak, Masturbacja w" Zachęcie, "Newsweck Polska" 2012 nr 51-52, 29 grudnia 2002, s. 195.

${ }^{37}$ Znamicnne przyklady takich opisów czytchnik nożc znalcźć niçdzy innymi w toniku nowel Grażyny Treli

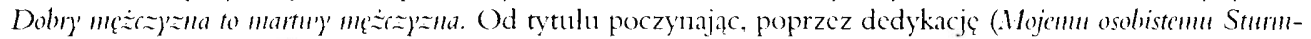
bahufiihrerou'i S. S.) po fabuly utworów przcbija z tomiku przemożna chęć epatowania skandalem (symptomatyczne sa pod tym względem sceny „gwaltu manuahego": absurd określenia dorównuje absurdowi i brakowi wyczucia smaku w kreśleniu sytuacji będącej tematem Zbocerica - picrwszego z dwu opowiadan sklada-

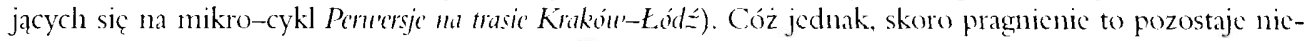
spehinone? Przywolywane przez Trelę sytuacje fabularne (sobowtór. zaprzedanie się pasji życia, perwersyjne gry miłosnc z niczuajomym) są w tóme i pozbawione prób rcinterpretacji. Sam skandal zaś zostaje - w tym i wielı innych przypadkach (choćby w powieściach Praszyúskicgo) - nicjako . oblaskawiony” i dostosowany do oczekiwań odbiorcy, tak by nic odczul on zgorszenia wiçkszego niz to. którego pragnąłby doświadczyć.

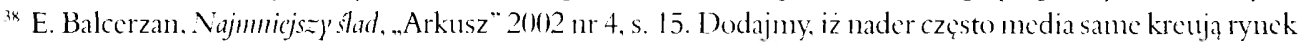
potrzeb (w tym - czytchniczych), na co zwraca uwage Robert Ostaszewski - zob.: Pisarz jak Coca Cola, .Dekada Literacka" $200+$ nu 1. s. 35-36.

${ }^{39}$ Warto przywolać w tym micjscu tez̨̧ Witolda (iombrowicza, który - w polemice z Janem Emilem Skiwskim (Earicuch uictaktóu', „Studio" 1936 ur 8) - pytal: ..Czy jeduak pan Skiwski uważa, ze literat nie ma prawa do nietaktu - o ile nictakt jest świadomy i shuzyć ma doprowadzeniu pod pióro nowych treści? Czy twórczość literacka nic polega między innymi na przcrabianin nictaktownego na taktowne i niesmacznego na smaczne? Czy zatem micjsce literata nic jest ma pograniczu nictaktu?". W przypadku wspólezesnej prozy operującej tym, co Gombrowicz nazywa „nictaktem”, nie można mówić o sygnalizowanych tu przez autora Fédydurke anbicjach. 